Тамара Бутиган Вучај

Народна библиотека Србије tamara@nb.rs
Стручни рад

UDK 316.722:02]:004.738.1(4)"2020" 616.98:578.834(100)"2020"

02-051:004.738.1(497.11)"2020"

https://doi.org/10.18485/bibliotekar.2020.62.2.2

\title{
МЕТУНАРОДНИ ПРОЈЕКТИ У ДОБА КОРОНЕ: ЈЕДНО ЛИЧНО ИСКУСТВО
}

Сажетак: Сви смо претходних месеци извесно искусили „корона ролеркостер” осећај. Иста метафора могла би да се примени на рад од куће, који је зависно од дана и активности попримао адреналинске или мелатонинске форме. Многима је ово било прво искуство рада од куће, будући да наше законодавство не препознаје овакву форму радног ангажовања. Прве анализе рада од куће у нашој земљи показале су да такав рад има и предности и мана, баш као и онај на радном месту. Ипак, неки од библиотекара имали су прилике да уче од већ искусних у раду од куће, путем међународних пројеката и активности. Ангажман у Европеани и другим међународним иницијативама, као и у неколико међународних пројеката, учинили су да тежак период карантина и пандемије буде прилика за учење и прилагођавање. А посебно преимућство представљало је учешће у серији онлајн радионица под називом Диіийална йрансформација у gоба ковиgа-19, коју је организовала Европеана за ограничени број полазника.

Кључне речи: међународни пројекти, Европеана, ковид-19, рад од куће, сектор културе, дигитална трансформација.

Први утисак који се наметнуо након почетка карантина био је да сви међународни партнери улажу ванредне напоре како би обезбедили посао/ плату за све запослене током рада од куће. Ту не треба губити из вида и услове за рад од куће у инфраструктурном смислу: хардвер и интернет везе. Ови услови су у богатим друштвима махом a priori испуњени, док то код нас није случај, тј. своде се на приватне капацитете запослених, што је додатно отежало ситуацију у којој су библиотеке и остале установе културе биле готово у потпуности затворене.

Пандемија ковида-19, која је изједначила исток и запад, богате и сиромашне, одважне и оне мање одважне, донела је један заједнички именитељ 
свим међународним пројектима и иницијативама. Наиме, сви физички догађаји и састанци су отказани, пре или касније, тако да је све пресељено у онлајн окружење. Иако су уштеде и предности оваквог начина комуникације очигледне, замор који изазива дужа комуникација путем екрана, као и немогућност емотивне комуникације, јасно указују на неопходност физичких састанака, барем за генерације бумера, како нас зову наши тинејџери.

Примери друштвеног ангажовања у време пандемије нису страни установама културе у Србији: израда заштитних визира, шивење маски и слично. Ипак, пример истраживачке добротворне организације „Wellcome Trust”, која је своју зграду у Лондону претворила у званични центар за одмор за медицинско особље болница Лондонског универзитетског колеџа, ипак је на врху моје листе ангажованости и друштвене одговорности установа културе у одговору на пандемију, иако је реч о установи која је приватна, а не државна. ${ }^{1}$ Здравствени радници лондонских болница у овој згради могли су да се окрепе, одспавају или забаве, у паузама дежурстава и борбе са болешћу ковид-19. Врх ове листе у Србији заузимају Народни музеј и Етнографски музеј у Београду, који су искористили своје збирке као мотиве за израду маски за лице и притом показали изузетну друштвену одговорност одричући се зараде. О овој иницијативи сам написала блог за Европеану: Претварање дигиталне уметности у дизајнерске маске за лице, ${ }^{2}$ који је објављен почетком августа.

Европеана је врло интензивно радила „од куће” како на редовним пословима, тако и кроз читав низ активности у вези са пандемијом. Већ у априлу, понудила је сјајне идеје за уметничке позадине ${ }^{3}$ за онлајн састанке и конференције, заправо дигиталне слике у јавном домену, које смо користили да бисмо избегли приказивање приватности спаваћих соба, кухиња и других кућних просторија у којима се одвијао рад од куће.

Свих шест Европеаниних заједница (истраживања, образовање, ИТ, ауторско право, комуникације и утицај) преселиле су своје активности на онлајн палтформе за видео комуникацију: Google Meet (за трајање догађаја

\footnotetext{
1 "Wellcome Trust building to become respite centre for local NHS staff", https://wellcome.org/ news/wellcome-trust-building-become-respite-centre-local-nhs-staff-covid-19 (преузето 14. 9. 2020).

2 Тамара Бутиган Вучај, “Turning digital art into designer face masks”, Европеана Про блог, 6. август 2020, https://pro.europeana.eu/post/turning-digital-art-into-designer-face-masks (преузето 14. 9. 2020).

3 Џолан Вајтс, “Art Up Your Zoom: beautiful backgrounds for your conference calls", Европеана Про блог, 3. април 2020, https://blog.europeana.eu/2020/04/art-up-your-zoom-beautifulbackgrounds-for-your-conference-calls/ (преузето 14. 9. 2020).
} 
до 60 минута и мањи број учесника) и Zoom (за трајање догађаја преко 60 минута и већи број учесника). Такође, сви Европеанини пројекти су настављени уз онлајн консултације. Европеана се још раније определила за политику високе свести о климатским променама, тако да су физички састанци и пре пандемије били сведени на минимум, а крајем године је организовала прву климатски одрживу конференцију. То практично значи следеће: као компензацију за карбонске отиске, произведене током авионских летова учесника конференције, Европеана је уплатила организацији "Trees for all” да посади 216 нових стабала у Холандији, на конференцији није било штампаног материјала и ради уштеде на пластичним или папирним чашама, сви учесници су добили флашице од лаке, рециклирајуће пластике. Европеанина Радна група за климатску акцију одгодила је кампању за очување климе, планирану за пролеће 2020, што не значи да није било онлајн дискусија о овоме. Уз констатације да је од почетка пандемије небо над Пекингом мало ведрије јер су смањени производња и обим саобраћаја, да има много мање летова авионом него последњих деценија те да је емисија угљен-диоксида унеколико смањена, морали смо да се сложимо да све то не зауставља климатске промене. Лед се и даље топи, ниво мора и температуре на нашој планети расту, неки инсекти и морски корали изумиру, а пластични отпад вреба на сваком ћошку. Баш крајем марта 2020, главни градови земаља на Балкану надметали су се индексима загађења који су износили између 300 и 400, што је означено као изузетно опасно по здравље. Тешко је замислити да послата е-пошта са прилогом од 1 MB производи 19 грама угљен-диоксида. И да се у свету за један сат пошаље више од 20 милијарди е-поште, што је равно карбонском отиску који направи 4.000 тона бензина. То су застрашујуће чињенице које нас инспиришу да бирамо нове начине размене и дељења информација и докумената.

У марту, првом месецу карантина, почео је циклус онлајн радионица „Култура од куће”, ${ }^{4}$ са фокусом на музеје, библиотеке, архиве и образовање, респективно, да би се почетком јула завршио радионицом са темом како организовати добар семинар. Све радионице је водила изузетна Сузан Хазан, координаторка конзорцијума Дигитално наслеђе из Израела и копредседавајућа Европеанине заједнице за комуникације, која је и иницирала ову серију онлајн радионица. Презентације и снимци са радионица доступни су онлајн. Сваки вебинар се након службеног завршетка програма

Сузан Хазан, “Culture from home - Connecting through webinars during the lockdown" https://pro.europeana.eu/post/culture-from-home-connecting-through-webinars-during-thelockdown, Европеана Про блог, 6. јул 2020. (преузето 14. 9. 2020). 
настављао слободним ћаскањем, такозваном Tana Libera Tutti (Слободно за све) сесијом, када би сви учесници могли да се виде, поделе утиске са радионице и слободно разговарају. У радионици намењеној библиотекама, примере добре праксе представиле су Марион Енсел и Луиза Торе из Националне библиотеке Француске и Софија Кларин Задравец из Националне и свеучилишне књижнице из Хрватске. Француска дигитална библиотека Галика појачала је активности на Твитеру, Инстаграму и Фејсбуку, као и број блогова о дигиталним садржајима, бирајући дигиталне садржаје примерене карантину. Занимљива је објава са предлогом за читање књиге из 18. века Пуй око моје собе 5 , Гзавијеа де Местра. Сви смо ишли на тај пут током карантина, а француски аутор подсећа како треба ценити оно што имамо. Против досаде код куће, обе библиотеке су користиле гејмификацију и осмислиле бројне игре за прекраћивање времена у карантину, али и учење о културном наслеђу. Посебна пажња посвећена је деци, прилично рањивој групи током пандемије. Национална и свеучилишна књижница (НСК) у Загребу креативно је приступила новој ситуацији изазваној пандемијом. Европски документациони центар при НСК придружио се промоцији Европске комисије за спречавање лажних вести и информација о пандемији. Хрватски архив веба, такође при НСК, покренуо је прикупљање веб-садржаја о коронавирусу SARS-CoV-2 и болести ковид-19. Такође, на друштвеним мрежама су постављани дигитални садржаји који промовишу мере за заштиту од заразних болести. У колекцији сувенира НСК понуђене су маске са мотивима из природе. Како је град Загреб током пандемије погодио и прилично јак земљотрес, НСК је пажњу усмерила на прикупљање информација о штети у мрежи библиотека као и архивирању веб-страница о земљотресу. Из старих хрватских новина, НСК је на друштвеним мрежама делила чланке о вирусним болестима и земљотресима кроз историју. Све бројнијој онлајн публици понуђене су нове виртуелне изложбе, тематске збирке дигитализованих садржаја, и то у сарадњи са другим библиотекама Хрватске. Недавно отворена Дигитална лабораторија НСК укључила се у израду визира за заштиту медицинског особља. На основу дигиталне грађе, креиране су бојанке ${ }^{6}$ и слагалице и то у неколико серија, тј. колекција. У слободном делу радионице било је речи

Галика, https://gallica.bnf.fr/ark:/12148/bpt6k65653101/, Национална библиотека Француске (преузето 14. 9. 2020).

6 Национална и свеучилишна књижница у Загребу, http://bojanka.nsk.hr/, Национална и свеучилишна књижница у Загребу (преузето 14. 9. 2020).

Национална и свеучилишна књижница у Загребу, http://slagalica.nsk.hr/, Национална и свеучилишна књижница у Загребу (преузето 14. 9. 2020). 
о промотивној акцији за популаризацију књига и читања \#bookfacefriday у којој подједнако узимају учешћа библиотеке и издавачке куће. Сазнали смо и да је Национална библиотека Шкотске отворила могућност за писање блогова (у форми писама библиотеци) од куће, како за запослене, тако и за кориснике, \#LettterstotheLibrary.

Прва онлајн конференција Европеане за време карантина био је пролећни Форум агрегатора за Европеану, који је одржан на апликацији Zoom ca преко 70 учесника, са одвојеним сесијама и радом по групама у одвојеним виртуелним просторима. За време пауза, Европеанин ди-џеј пуштао је музику из јавног домена, а други дан био је у целости посвећен ауторском праву у дигиталном свету и одређивању лиценци за приступ дигитализованим садржајима, што је од изузетног значаја за праксу дигиталних библиотека у Србији. Поред практичне радионице, спроведено je ad hoc истраживање помоћу софтвера Mentimeter. Ова дводневна конференција одржана је у првој седмици маја и коначно нас уверила да се и велика тродневна годишња конференција Европеане може одржати онлајн у новембру 2020. године.

Други годишњи састанак Савета чланова Асоцијације Мрежа Европеана, који је требало да се одржи у Хагу почетком јула, такође је мигрирао у виртуелни свет. То је можда био и најзанимљивији стручни онлајн догађај у коме сам учествовала. Он је још једном доказао да као и у физичком свету и у оном онлајн, избор правих људи за вођење сесија представља кључ успешности било ког скупа. На једној од сесија учили смо да правимо мимове базиране на грађи Европеане, на крају смо их објавили на Твитеру, што је било забавно, а некима и јако корисно.

Пројекат Заједничка култура, који са Европеаном спроводе 24 европске институције са циљем да се креира координирано окружење за националне агрегаторе за Европеану, продужен је за шест месеци, пре свега због обимности, али и услед отежаног рада због пандемије, тако да уместо до краја јуна траје до краја децембра 2020. године. Народна библиотека Србије, као партнер у пројекту, наставила је са свим активностима које су биле могуће у новим условима, а то је пре свега рад на унапређивању метаподатака и креирању ПДФ докумената у пуном тексту за дигиталне објекте из Народне библиотеке Србије. Пројектни тим имао је непрекидну онлајн комуникацију на апликацији Slack и доста тога смо успели да завршимо радом од куће.

Током вишемесечног карантина, из већ завршеног пројекта Процват писмености, Европеана је објавила читав низ блогова партнерских установа, а међу њима и два блога из Народне библиотеке Србије: Рођен ga 


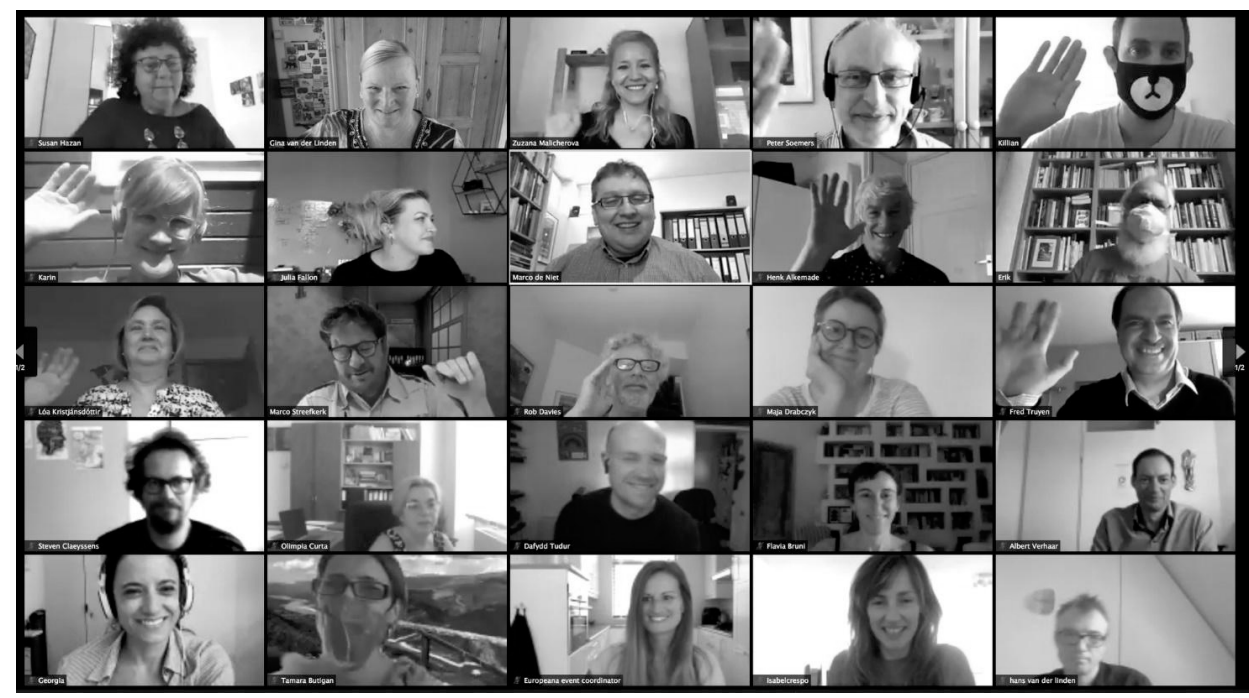

Фотографија једног броја учесника онлајн састанка Савета чланова Асоцијације Мрежа Европеана

би био заборављен ${ }^{8}$ Душана Никодијевића и Пуйник - иррича о Милораgу Рајчевићу Ане Стевановић.

PAGODE Европеана Кина нови је пројекат започет у априлу 2020. године. Припрема наставка овог пројекта PAGODE 2 текла је за време пандемије. Из Србије су аплицирали Народни музеј у Београду и Универзитетска библиотека „Светозар Марковић”. Карантин није много утицао на окупљање пројектног тима и прикупљање документације јер се то и иначе одвија онлајн, уз велики број сати проведених на онлајн састанцима.

Пројекат ADRINETBOOK из европског програма финансирања INTERREG припада фамилији европских пројеката за подршку јонскојадранском региону. За овај програм финансирања Србија је квалификована већ дужи низ година. Народна библиотека Србије позвана је да учествује у овом пројекту од Централног института за обједињени каталог

8 Душан Никодијевић, “Born to be Forgotten - the story of Božidar Knežević”, 21. април 2020, https://blog.europeana.eu/2020/04/born-to-be-forgotten-the-story-of-bozidar-knezevic/ (преузето 15. 9. 2020).

9 Ана Стевановић, “The Traveller - story of Milorad Rajčević”, Европеана блог, 19. мај 2020, https://blog.europeana.eu/2020/05/the-traveller-story-of-milorad-rajcevic/ (преузето 15. 9. 2020). 
из Рима, која је и водећи партнер у пројекту. Вишегодишње припреме за покретање пројекта окончане су почетком марта 2020, када је пројекат и званично почео. Због ситуације са пандемијом у Италији, пролонгиране су активности у овом пројекту за јесен, што не значи да је изостала онлајн преписка и различите активности.

Европеанина Радна група за истраживаче бави се дигиталном трансформацијом установа културе Европе и њихових дигиталних садржаја како би били пријемчивији за истраживаче који се пре свега декларишу као дигитални хуманисти. Ова група је интензивно радила онлајн на припреми смерница за установе културе и Европеану, полазећи од упитника који је спроведен међу истраживачима током октобра 2019. године. Пандемија је у великој мери изменила хоризонт истраживача. Џенифер Едмондс, једна од троје директора европског конзорцијума DARIAH-ERIC, наводи: „Ковид-19 је убрзао темпо и видљивост дељених истраживања, како у науци, тако и у уметности (на пример, на тему искустава са пандемијом грипа 1918. године или развоја и дистрибуције ранијих вакцина). Међутим, установе културе нису тако спремне за брзе и примењиве одговоре. Ово је одлична прилика за уметност и хуманистичке науке да покушају да допринесу извеснијој перспективи друштва у време великих изазова које наука, технологија, инжењерство и математика не могу решити саме."

Европеана континуирано ради на оснаживању сектора културног наслеђа у његовој дигиталној трансформацији. У склопу своје мисије, покренула је „процес стварања смисла” (sense-making process), у јуну 2020. године кроз тронедељне радионице са 64 учесника из 22 земље, под насловом Диіитиална йрансформација у gоба ковиgа-19. Смисао овог процеса је да идентификује потенцијалне могућности за развој и позитивно деловање током кризе изазване болешћу ковид-19. Мајкл Питер Едсон (стратег, консултант и лидер у области дигиталне трансформације у култури) и Јаспер Висер (међународни консултант и водитељ, специјализован за област дигиталне трансформације, Музеји будућности ${ }^{10}$ ), независни експерти, водили су учеснике, подељене у три групе, кроз десет тема, да би се кроз разговор спонтано наметнуло још барем десет. Задате теме биле су: прилика за промене, нова перспектива дигиталног, друштвени утицај и релевантност, корисници и различитост, наше основне вредности и култура, превазилажење дигиталног јаза, организација културног наслеђа, умрежени сектор културе, индивидуални раст и учење, простор за иновације и

10 Музеји будућности, https://themuseumofthefuture.com/, Јасперс Висер (преузето 15. 9. 2020). 
експериментисање. Неке од наметнутих биле су: реакција сектора културе на покрет Black Lives Matter, култура рада од куће, реевалуација физичких састанака и многе друге. Учесници су током онлајн састанака износили своја виђења и одговоре на унапред задата питања, да би након тога радили домаће задатке, кроз онлајн упитнике. Двоје учесника било је из Србије: Адам Софронијевић из Универзитетске библиотеке „Светозар Марковић” и Тамара Бутиган Вучај из Народне библиотеке Србије, наравно у различитим групама, које су формиране тако да буду родно и географски балансиране. Теме које смо обрађивали наводиле су нас да додатно промислимо о новој ситуацији у којој смо се нашли, о променама које нас извесно очекују, а све кроз могућност да разменимо и укрстимо мишљења и почнемо да пројектујемо могућа решења за будућност наших занимања, али и институција. Први налази и исходи овог процеса објављени су крајем јуна као нацрт и стављени на увид Савету чланова Асоцијације мреже Европеана, као део агенде другог годишњег састанка овог тела. Од 34 члана Савета, њих 15 је учествовало у овим радионицама. Слободно се може рећи да је циљ радионица постигнут: подстакнут је дијалог представника сектора културног наслеђа широм Европе и створени су услови за почетак деловања. Један од могућих закључака ове правовремене иницијативе јесте да је нови изазов да будемо иновативни, а не да само конвертујемо физичке активности у дигиталне, што је у некој мери наравно неопходно. Запажа се једна врста императива да се прихвати изазов промене, иако не знамо да ли ће правац промене бити прави. Често нам треба храбрости да отворимо теме које нису увек пријатне. И уколико сами мислимо да нисмо важни за друштво, тако ће нас друштво и перципирати, што значи да треба да мењамо ставове. Такође, установе културе налазе се у својеврсном парадоксу или кваки-22: иницијативе унутар дигиталне трансформације захтевају финансијска улагања, која су у новим условима смањена у читавом сектору културе. Финансијски ефекти пандемије и те како се одражавају на установе културе и појединце, готово све наплативе услуге су сведене на минимум, буџети су редуковани. са друге стране, дигитални јаз препознајемо у најмање три облика: као технолошки, унутар сектора (између библиотека, архива, музеја и галерија) и унутар самих установа, међу колегама.

Све у свему, ситуација у којој смо се нашли подсећа на ону у којој конструишемо летелицу којом увелико летимо. 


\section{Криза изазвана ковидом-19 Период транзиције Нова нормалност}

Будућност сектора културе, укључујући и дигиталну трансформацију овог сектора, никада није била неизвеснија, баш као и будућност света у којем живимо и који смо створили за будуће генерације. Ако је нешто потпуно извесно, то су промене и било би добро да их прихватимо и пригрлимо, уколико желимо да будемо део будућности и то као библиотекари, као важни субјекти сектора културе и на крају као носиоци промена и лидери у дигиталној трансформацији. 


\section{Literatura:}

1. Butigan Vučaj, Tamara. "Turning digital art into designer face masks". Evropeana Pro blog, 6. avgust 2020, https://pro.europeana.eu/post/turning-digital-art-into-designer-face-masks (preuzeto 14. 9. 2020).

2. Galika, https://gallica.bnf.fr/ark:/12148/bpt6k65653101/, Nacionalna biblioteka Francuske (preuzeto 14. 9. 2020).

3. Hazan, Suzan, "Culture from home - Connecting through webinars during the lockdown" https://pro.europeana.eu/post/culture-from-home-connecting-through-webinars-during-the-lockdown, Evropeana Pro blog, 6. juli 2020. (preuzeto 14. 9. 2020).

4. Muzeji budućnosti, https://themuseumofthefuture.com/, Jaspers Viser (preuzeto 15. 9. 2020).

5. Nacionalna i sveučilišna knjižnica u Zagrebu, http://bojanka.nsk.hr/, Nacionalna i sveučilišna knjižnica u Zagrebu (preuzeto 14. 9. 2020).

6. Nacionalna i sveučilišna knjižnica u Zagrebu, http://slagalica.nsk.hr/, Nacionalna i sveučilišna knjižnica u Zagrebu (preuzeto 14. 9. 2020).

7. Nikodijević, Dušan, "Born to be Forgotten - the story of Božidar Knežević", 21. april 2020, https://blog.europeana.eu/2020/04/born-to-be-forgotten-the-story-ofbozidar-knezevic/ (preuzeto 15. 9. 2020).

8. Stevanović, Ana, "The Traveller - story of Milorad Rajčević”, Evropeana blog, 19. maj 2020, https://blog.europeana.eu/2020/05/the-traveller-story-of-milorad-rajcevic/ (preuzeto 15. 9. 2020).

9. Vajts, Džolan, "Art Up Your Zoom: beautiful backgrounds for your conference calls", Evropeana Pro blog, 3. april 2020, https://blog.europeana.eu/2020/04/ art-up-your-zoom-beautiful-backgrounds-for-your-conference-calls/ (preuzeto 14. 9. 2020).

10. "Wellcome Trust building to become respite centre for local NHS staff", https://wellcome.org/news/wellcome-trust-building-become-respite-centre-local-nhs-staff-covid-19 (preuzeto 14. 9. 2020). 


\title{
Tamara Butigan Vučaj
}

National Library of Serbia, Belgrade

tamara@nb.rs

\section{INTERNATIONAL PROJECTS IN THE TIME OF CORONAVIRUS: A PERSONAL EXPERIENCE}

\begin{abstract}
We have all experienced the "coronavirus roller coaster" feeling in the previous months. The same metaphor could be applied to work from home, which took adrenaline or melatonin forms depending on the day and activity. For many of us, this was the first experience of working from home, since Serbian legislation does not recognize this form of work engagement. The first analyzes of work from home in our country have shown that such work has both advantages and disadvantages, just like the one in the workplace. However, some of the librarians had the opportunity to learn from those already experienced in working from home, through international projects and activities. Engagement in Europeana and other international initiatives, as well as in several international projects, have made the difficult period of quarantine and pandemic an opportunity for learning and adaptation. And a special advantage was the participation in a series of online workshops Digital Transformation in the time of COVID-19, organized by Europeana for a limited number of participants.
\end{abstract}

Keywords: international projects, Europeana, COVID-19, work from home, cultural sector, digital transformation.

Примљено: 20. септембра 2020.

Прихваћено: 6. новембра 2020. 